\title{
Frequency of malocclusion and condition of dental health among eight-year-old children in the municipality of Foča
}

\author{
Marina Milinković1, Tanja Ivanović1, Predrag Nikolić², Ljiljana Stojanović Željko Milosavljević2 \\ Jovana Samardžija Hrisa ${ }^{1}$, Aleksandra Šarac ${ }^{3}$ \\ 'University of East Sarajevo, Faculty of Medicine, Department of Dentistry, Foča, Bosnia and Herzegovina; \\ ${ }^{2}$ University of Belgrade, School of Dental Medicine, Department for Orthodontics, Belgrade, Serbia; \\ ${ }^{3}$ Health Center Sokolac, Bosnia and Herzegovina
}

\begin{abstract}
SUMMARY
Introduction Caries and orthodontic anomalies in school-age children lead to disturbed aesthetics, oral functions (chewing, swallowing, and speech), predisposition to trauma and the onset of periodontal diseases.

The aim was to assess dental health and frequency of orthodontic anomalies in children aged 8-9 years in the municipality of Foča.

Methods The research was conducted in the primary school Sveti Sava in Foča, where the total of 112 children age 8-9 years were examined. An informed consent was obtained from parents and school director for each student. Dental examination was performed using standard dental method, a mirror and a probe under artificial lighting. Children received instructions on proper nutrition, oral hygiene, tooth protection and elimination of bad habits.

Results Among 112 examined boys and girls of selected ages, very high person caries index (PCl) was found (78.57\%). A total of 548 caries affected teeth were found (boys $331(24.62 \%)$, girls $217(16.14 \%)(p<0.05))$. Fifty-nine children had caries lesions on permanent teeth (boys 39 (2.9\%), girls $20(1.5 \%)(p<0.05)$ ). Sagital abnormalities of the bite were present in 39 (34.82\%) children, while $38(33.92 \%)$ anomalies were related to vertical bite irregularities, 10 (8.92\%) of them had open bite and 28 subjects (25\%) had deep bite ( $p>0.05)$. Conclusion Large number of teeth was affected with caries lesions (548) in eighth-year-olds, while orthodontic anomalies, mostly sagital abnormalities of bite were found in 39 subjects.

Keywords: caries; malocclusion; orthodontics; eight-year-olds
\end{abstract}

\section{INTRODUCTION}

Oral diseases and disorders have an important place in human pathology and can negatively affect the quality of life in children [1]. Caries and periodontitis are the most prevalent diseases of modern age. Children are the most commonly affected with caries lesions that have profound effect on aesthetic and function of oro-facial region [2]. Different factors (general and local, internal and external) are related to the emergence of caries. These are: race, hereditary factors, individual lifespan, gender, endocrine gland function, nutrition, microorganisms, saliva, form and arrangement of teeth, iatrogenic factors, poor oral hygiene and others [3]. Maloclusion is disorder of normal occlusion [4]. It has multifactorial origin (genetic and hereditary components, irregular nutrition, teeth caries, overdose teeth and premature loss of teeth) [5].

Orthodontic anomalies and dental caries of the two most widespread dental diseases in children, and the fact that they are in constant rise, indicates their mutual relation and conditionality [6]. It is known that caries lesions and especially those on the proximal surfaces of primary teeth have major influence on orthodontic anomalies. In addition, any premature extraction of primary mo- lars causes secondary anxiety [7]. Since the best time to start orthodontic therapy is pre-puberty, the goal of our research was to determine oral status and the presence of malocclusion in eight-year-olds in the municipality of Foca, and compare obtained results with those from other parts of $B \& \mathrm{H}$, countries in the region, or some more developed countries in the world.

\section{MATERIAL AND METHODS}

This study was done in the municipality of Foča, where a total of 112 children aged 8-9 years were examined (second and third grade). The selected year is relevant because of the period of mixed dentition, teeth shifting and pre-puberty growth when treatment with orthodontic mobile devices provides the best effects. The study was conducted in 2017 in the elementary school Sveti Sava in Foča. Dentists from the Department of Pediatric and Preventive Dentistry with Orthodontics carried out the examinations. Prior to the beginning of examination, parents, the school director and the Ministry of Education and Culture of Repuplika Srpska signed written consent for participation in the study for each child. Children who 
did not have written consent from their parents were excluded from the study. The Ethics Committee of the Faculty of Medicine in Foca also approved the study. The main activities during the research were: health education of children, examination of mouth and teeth, dental card records, group health interview with children, individual health interview with parents and teachers on how to maintain oral hygiene and advise parents on correct diet.

Prior to each examination, children were lectured in the presence of teaching staff about the importance of healthy teeth for general health, the process of caries formation, the process of plaque formation, the effects of microorganisms from toothache, the importance of proper nutrition for the health of teeth, the way to maintaining proper oral hygiene, the importance and significance of fluoride prophylaxis, the importance of fissure sealants, the type of accessories necessary for the maintenance of oral hygiene, as well as the importance of control checkups. The proper maintenance of oral hygiene was also demonstrated to the students.

The examinations were carried out in classrooms under daylight using dental probe and mirror. The KleinPalmer System (DMFT) was used to assess the prevalence of caries. For each child the presence or absence of orthodontic anomalies was recorded. Based on the occlusal relationship between the teeth of the upper and lower jaws, the class was determined by Angle. Vertical irregularities of the bite were measured using an orthodontic millimeter liner.

For the statistical data processing, the non-parametric test, Chi-square test, and the parametric test, t-test for independent samples were used, at a probability level of $5 \%(\mathrm{p}<0.05)$.

\section{RESULTS}

Clinical examination provided data on teeth status, mutual interaction of dental cavities and the presence of orthodontic anomalies. In 112 surveyed boys and girls, $40.77 \%$ of teeth were affected with caries lesions (boys $(24.62 \%)$; girls $(16.14 \%))(\mathrm{p}<0.05)($ Table 1]). Caries lesions were found in permanent teeth in $4.38 \%$ of subjects (boys $(2.9 \%)$ and girls $(1.5 \%))(\mathrm{p}<0.05)$ (Table 2). Caries Person Index (CPI) was very high-78.57\% (boys $55.68 \%$; girls $34.82 \%(\mathrm{p}>0.05))$.

Also, high percentage of orthodontic anomalies was found in examined children. Sagittal abnormalities were found in $34.82 \%$ of respondents $(18.2 \%$ boys, $16.6 \%$ of girls, ( $p>0.05)$. As per Angle classification the most common class found was class I in $65.17 \%$ of respondents (Table 3), where $47.32 \%$ had class I with no malocclusion while $17.85 \%$ had class I with malocclusion $(\mathrm{p}<0.05)$.

The most frequent irregularity of biting was the class II, which was registered in $26.78 \%$ of respondents. Class II/1 characterized by distal bite with protrusion of upper teeth was found in $16.96 \%$ of children, while class II/2 with distal bite and upper teeth retrusion was registered in $9.82 \%$ of children (Table 3 ). The lowest number of bite irregularities was related to class III malocclusion that was
Table 1. Distribution of carious teeth in primary dentition Tabela 1. Raspodela karijesa u mlečnoj denticiji

\begin{tabular}{|l|c|c|c|}
\hline & K (D) & E (E) & P (F) \\
\hline $\begin{array}{l}\text { Boys } \\
\text { Dečaci }\end{array}$ & $331(24.62 \%)$ & $44(3.27 \%)$ & $21(1.56 \%)$ \\
\hline $\begin{array}{l}\text { Girls } \\
\text { Devojčice }\end{array}$ & $217(16.14 \%)$ & $37(2.75 \%)$ & $24(1.78 \%)$ \\
\hline $\begin{array}{l}\text { Total } \\
\text { Ukupno }\end{array}$ & $548(40.76 \%)$ & $81(6.02 \%)$ & $45(3.34 \%)$ \\
\hline $\begin{array}{l}\text { P value } \\
\text { P vrednost }\end{array}$ & & $\mathrm{p}<0.05$ & \\
\hline
\end{tabular}

$D$ - decayed, E - extracted, $F$ - filled tooth

$\mathrm{K}$ - karijes, E - izvađen, $\mathrm{P}$ - plombiran zub

Table 2. Distribution of carious teeth in permanent dentition Tabela 2. Raspodela karijesa u stalnoj denticiji

\begin{tabular}{|l|c|c|c|}
\hline & K (D) & E (E) & P (F) \\
\hline $\begin{array}{l}\text { Boys } \\
\text { Dečaci }\end{array}$ & $39(2.9 \%)$ & $10(0.74 \%)$ & $13(0.9 \%)$ \\
\hline $\begin{array}{l}\text { Girls } \\
\text { Devojčice }\end{array}$ & $20(1.5 \%)$ & $8(0.6 \%)$ & $15(1.1 \%)$ \\
\hline $\begin{array}{l}\text { Total } \\
\text { Ukupno }\end{array}$ & $59(4.4 \%)$ & $18(1.34 \%)$ & $28(2.0 \%)$ \\
\hline $\begin{array}{l}\text { P value } \\
\text { P vrednost }\end{array}$ & & $\mathrm{p}<0.05$ & \\
\hline
\end{tabular}

D - decayed, E - extracted, F - filled tooth

$\mathrm{K}$ - karijes, $\mathrm{E}$ - izvađen, $\mathrm{P}$ - plombiran zub

Table 3. Distribution of orthodontic malocclusions per Angle in boys and girls

Tabela 3. Raspodela ortodontskih nepravilnosti po Angleu među dečacima i devojčicama

\begin{tabular}{|l|c|c|c|c|c|}
\hline & $\begin{array}{c}\text { class I } \\
\text { I klasa }\end{array}$ & $\begin{array}{c}\text { class II } \\
\text { II klasa }\end{array}$ & $\begin{array}{c}\text { class II/1 } \\
\text { II/1 klasa }\end{array}$ & $\begin{array}{c}\text { class II/2 } \\
\text { II/2 klasa }\end{array}$ & $\begin{array}{c}\text { class III } \\
\text { III klasa }\end{array}$ \\
\hline $\begin{array}{l}\text { Boys } \\
\text { Dečaci }\end{array}$ & $\begin{array}{c}35 \\
(31.25 \%)\end{array}$ & $\begin{array}{c}13 \\
(11.60 \%)\end{array}$ & $\begin{array}{c}11 \\
(9.82 \%)\end{array}$ & $5(4.46 \%)$ & $5(4.46 \%)$ \\
\hline $\begin{array}{l}\text { Girls } \\
\text { Devojčice }\end{array}$ & $\begin{array}{c}38 \\
(33.92 \%)\end{array}$ & $\begin{array}{c}17 \\
(15.17 \%)\end{array}$ & $8(7.14 \%)$ & $6(5.35 \%)$ & $4(3.57 \%)$ \\
\hline $\begin{array}{l}\text { Total } \\
\text { Ukupno }\end{array}$ & $\begin{array}{c}73 \\
(65.17 \%)\end{array}$ & $\begin{array}{c}30 \\
(26.78 \%)\end{array}$ & $\begin{array}{c}19 \\
(16.96 \%)\end{array}$ & $\begin{array}{c}11 \\
(9.82 \%)\end{array}$ & $9(8.03 \%)$ \\
\hline $\begin{array}{l}\text { P value } \\
\text { P vrednost }\end{array}$ & & & $\mathrm{p}>0.05$ & & \\
\hline
\end{tabular}

found in $8.03 \%$ of subjects $(\mathrm{p}>0.05)$ (Table 3). A dentoalveolar class III with simple inversed incisor contacts as the most form of class III was registered in $6.72 \%$ children (Figure 1).

In relation to the vertical plane, bite irregularities were found in $33.92 \%$ of children. Open bite was present 10 (8.92\%) subjects, while 28 (25\%) of subjects had some form of deep bite ( $>0.05)$ (Figure 2) (Table 4).

\section{DISCUSSION}

In our study, high prevalence of caries was observed among school children in the municipality of Foča. Based on previous studies and reviewed literature, it is known that socio-demographic factors, parents and cooperation with dental service have an impact on children general health. According to the obtained high values of person caries index (PCI-78.57\%), Foča municipality is among leading ones with frequent occurrence of caries lesions. These results are in accordance with the results of 


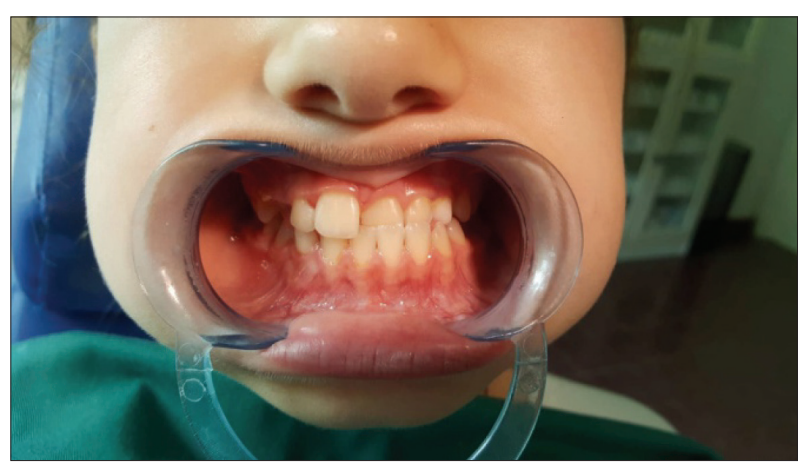

Figure 1. Simple inverted bite of incisors

Slika 1. Obrnuti preklop sekutića

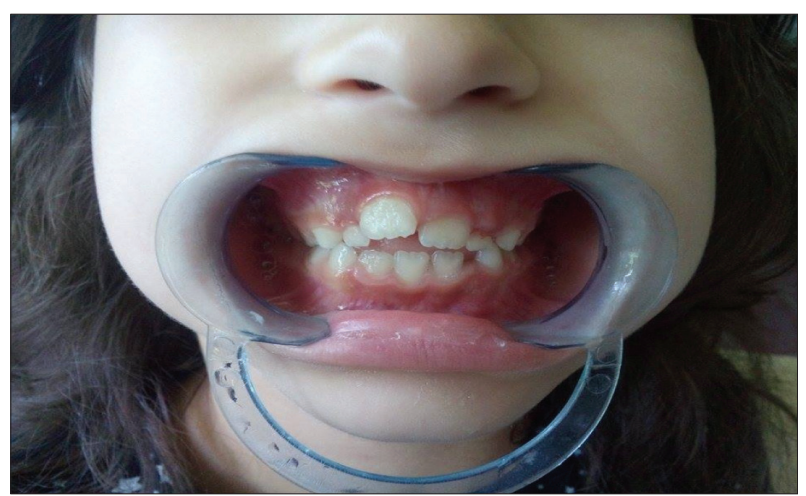

Figure 2. Open bite

Slika 2. Otvoreni zagrižaj

Table 4. Distribution of vertical bite irregularities in eight-year-olds Tabela 4. Raspodela vertikalnih nepravilnosti zagrižaja među osmogodišnjacima

\begin{tabular}{|l|c|c|c|}
\hline & $\begin{array}{c}\text { Vertical irregularities } \\
\text { in bite } \\
\text { Vertikalne nepravilnosti } \\
\text { zagrižaja }\end{array}$ & $\begin{array}{c}\text { Deep bite } \\
\text { Duboki } \\
\text { zagrižaj }\end{array}$ & $\begin{array}{c}\text { Open bite } \\
\text { Otvoreni } \\
\text { zagrižaj }\end{array}$ \\
\hline $\begin{array}{l}\text { Boys } \\
\text { Dečaci }\end{array}$ & $18(16.07 \%)$ & $12(10.71 \%)$ & $6(5.35 \%)$ \\
\hline $\begin{array}{l}\text { Girls } \\
\text { Devojčice }\end{array}$ & $20(17.85 \%)$ & $16(14.28 \%)$ & $4(3.57 \%)$ \\
\hline $\begin{array}{l}\text { Total } \\
\text { Ukupno }\end{array}$ & $38(33.92 \%)$ & $28(25 \%)$ & $10(8.92 \%)$ \\
\hline $\begin{array}{l}\text { P value } \\
\text { P vrednost }\end{array}$ & & $p>0.05$ & \\
\hline
\end{tabular}

Davidović et al. [8] who found $43.5 \%$ of children with caries in the area of the eastern part of B \& H. Also, Kobašlija et al. (2000) found high values of PCI (89\%) in Sarajevo municipality [9]. These findings are typical for underdeveloped or developing countries to have high values of PCI (87-91\%) [10], compared to developed countries where PCI is significantly lower $(28.8 \%)[11,12]$.

The above results can be related to number of carious teeth in mixed dentition in some European countries [13], where higher values of carious teeth (44.6\%) were found in school children. However, European countries have significantly higher (55.4\%) number of children with all healthy teeth, whereas in our country only $21.4 \%$ of children are reported with all healthy teeth. Considering that significantly large number of eight-year-olds has high frequency of carious and extracted then filled teeth, it is clear that long-term preventive programs and systematic dental care are non-existing in our country.

Previous research in the area of Bosnia and Herzegovina and neighboring countries $[8,9,10]$ showed high prevalence of caries of permanent teeth in schoolchildren (45-88.35\%). Our study showed significantly lower (4.1\%) frequency of caries at this age compared to previous studies, which can be explained by the fact that it was period of early mixed dentition and only recently erupting permanent teeth were present. But when we look at the distribution of DMFT, we noticed significantly more carious teeth compared to filled teeth, especially in boys, with clear indication of weaker preventive and prophylactic measures and cooperation with dentist.

In addition, orthodontic anomalies were found in $52.67 \%$ children and that was the highest frequency found compared to other similar research in domestic and foreign literature, where the percentage of these anomalies varied from $29.42-81 \%[8,14]$.

In our study, the most common form of malocclusion according to Angle Classification was Class I (65.17\%), and that is consistent with the results from earlier studies $(62.9 \%)[14,15,16] .47 .32 \%$ of subjects had normal occlusion class I, which is significantly higher than in the results of other studies (6.5-10\%), while malocclusion of the class I with crowding in the anterior teeth accounted for a total of $17.85 \%$, that is lower than in the world population [14]. The frequency of the class II $(26.78 \%)$ was lower in our study compared to the results of other studies where the percentage of these anomalies was significantly higher $(58-65 \%)[17,18]$. This could be explained by the lower prevalence of bad habits and successful application of preventive and interceptive orthodontic measures in the period of deciduous dentition. Also, results showed that II/1 was more pronounced in relation to the class II/2, which is in line with previously published studies where class II/1 (35\%) was more prevalent than the class II/2 (17\%) [8].

Class III malocclusion was present in $8.03 \%$, which is more than in European countries (2.5\%) [19]. As higher percentage $(6.72 \%)$ of this malocclusion relates to children with simple inversion of incisors, this percentage can be explained by poor application of interceptive and preventive measures at an early age that has great effect in the treatment of orthodontic anomalies [20].

Vertical bite irregularities in this study were found in a total of $33.92 \%$ subjects. In relation to the world population, where deep bite malocclusion is found in $30-50 \%$ of children, in our study deep bite was found in $25 \%$, which is less compared to other studies [20]. Our results are similar to the study conducted by Jovic et al. [21] that showed bite depth is changing at intervals and bite becomes deeper in the period of 7-10 years. These data also coincide with the prevalence of the class II/2, which is associated with deep and distal bite. Open bite was registered in a total of $8.92 \%$ of children, which is significantly lower compared to other studies where the prevalence of this anomaly was considerably higher (26.7\%) [22]. This can be explained with lower incidence of bad habits in the eighth year olds that are the main etiological factor in the onset of open bite. 


\section{CONCLUSION}

The prevalence of orthodontic anomalies in the selected sample of school children in the municipality of Foča was high. The most commonly registered was class II, deep bite, anterior crowding, open bite and inverted bite of incisors. The frequency of caries in the total sample (PCI) was very high, and higher for boys than girls. In order to preserve deciduous teeth as a protector of space and supporting zone, it is necessary to introduce mandatory restoration of deciduous teeth before enrolling in schools, as well as regular preventive- prophylactic and interceptive measures in order to prevent the occurrence of serious orthodontic problems at a later age.

\section{REFERENCES}

1. Jenny J, Cons NC. Comparing and contrasting two orthodontic indices, the index of orthodontic treatment need and the Dental Aesthetic Index. Am J Orthod Dentofacial Orthop. 1996; 110(4):410-6. [DOI: 10.1016/S0889-5406(96)70044-6] [PMID: 8876493]

2. Shashank SG, Anjali G, Laxmikant K, Sandeep P, Vivek P, Madhura F. Dental caries and its relationship to malocclusion in permanent dentition among 12-15 year old school going children. I Int Oral Health. 2014; 6(5):27-30. [PMID: 25395789]

3. Onyeaso CO, Aderinokun GA. The relationship between dental aesthetic index (DAl) and perceptions of aesthetics, function and speech amongst secondary school children in Ibadan, Nigeria. Int J Paediatr Dent. 2003; 13(5):336-41. [DOI: 10.1046/j.1365263X.2003.00478.x] [PMID: 12924989]

4. Mahesh Kumar P, Joseph T, Varma R, Jayanthi M. Oral health status of 5 years and 12 years school going children in Chennai city, An epidemiological study. I Indian Soc Pedod Prev Dent. 2005; 23(1):17-22. [DOI: 10.4103/0970-4388.16021] [PMID: 15858301]

5. Bittencourt MAV, Machado AW. An overview of the prevalence of malocclusion in 6 to 10-year-old children in Brazil. Dental Press J Orthod. 2010; 15(6):113-22. [DOI: 10.1590/S217694512010000600015]

6. Radica-Sorić V. Povezanost zubnog karijesa i ortodontskih anomalija u mliječnoj denticiji. Acta stomatologica Croatica.1979; 13(3):119-23.

7. Baskaradoss JK, Geevarghese A, Roger C, Thaliath A. Prevalence of malocclusion and its relationship with caries among school children aged 11-15 years in southern India. Korean J Orthod. 2013; 43(1):35-41. [DOI: 10.4041/kjod.2013.43.1.35] [PMID: 23503064]

8. Davidović B, Janković S, Ivanović D, Ivanović T, Vulićević Z, Ivanović $M$, et al. Procjena uticaja promocije oralnog zdravlja u djece istočnog dijela Republike Srpske. Biomedicinska istraživanja. 2011; 2(1):11-9. [DOI: 10.7251/B\|11101016D]

9. Kobašlija S, Maglajlić N, Huseinbegović A. Prevalencija karijesa u djece u Sarajevu. Acta Stomatol Croat. 2000; 34(1):83-5.

10. Djuričković M, Ivanović M. Stanje oralnog zdravlja kod djece uzrasta od 12 godina u Crnoj Gori. Vojnosanitetski pregled. 2011; 68(7):550. [DOI: 10.2298/VSP1107550D]

11. Paisi M, Kay E, Kaimi I, Witton R, Nelder R, Christophi C, et al. Obesity and dental caries in young children in Plymouth, United Kingdom: A spatial analysis. Community Dent Health. 2018; 35(1):58-64. [DOl: 10.1922/CDH_4214Paisi07] [PMID: 29380963]

12. Hobdell M, Petersen PE, Clarkson J, Johnson N. Global goals for oral health 2020. Int Dent J. 2003; 53:285-8. [DOI: 10.1111/j.1875595X.2003.tb00761.x]

13. Luzzi V, Fabbrizi M, Coloni C, Mastrantoni C, Mirra C, Bossù M, et al. Experience of dental caries and its effects on early dental occlusion: a descriptive study. Ann Stomatol (Roma). 2011; 2(1-2):13-8. [PMID: 22238717]

14. Patil D, Poornima P, Manoharan M. Malocclusion and dental caries experience among 8-9-year-old children in a city of South Indian region: A cross-sectional survey. J Educ Health Promot. 2017; 6:98. [DOI: 10.4103/jehp.jehp_24_17] [PMID: 29296599]

15. Silva RG, Kang DS. Prevalence of malocclusion among Latino adolescents. Am J Orthod Dentofacial Orthop. 2001; 119:313-5. [DOl: 10.1067/mod.2001.110985] [PMID: 11244426]

16. Thilander B, Pena L, Infante C, Parada SS, de Mayorga C. Prevalence of malocclusion and orthodontic treatment need in children and adolescents in Bogota, Colombia. An epidemiological study related to different stages of dental development. Eur J Orthod. 2001; 23:153-67. [PMID: 11398553]

17. Fundagul B, Ibrahim EG, Ahmet AC. Malocclusion prevalence and orthodontic treatment need in central Anatolian adolescents compared to European and other nations' adolescents. Dental Press J. Orthod. 2015; 20(6). [DOI: 10.1590/2177-6709.20.6.075-081. oar] [PMID: 26691973]

18. Redzepagic V, llic Z, Laganin S, Dzemidzic V, Tiro A. An epidemiological study of malocclusion and occlusal traits related to different stages of dental development. South Eur J Orthod Dentofac Res. 2017; (4)1:9-13. [DOI: 10.5937/sejodr4-1285]

19. Otto S, Patricia AS, Anna S, Adriano C. Orthodontic treatment need of austrian schoolchildren in the mixed dentition stage. Swiss Dent J. 2017; 127(2): 122-8. [PMID: 28266685]

20. Gudipaneni RK, Aldahmeshi RF, Patil SR, Alam M. The prevalence of malocclusion and the need for orthodontic treatment among adolescents in the northern border region of Saudi Arabia: an epidemiological study. BMC Oral Health. 2018; 2:18. [PMID: 29390986]

21. Jović M, Kravić K, Trifunović M. Promena dubine preklopa sekutića kod dece za vreme smene zuba. ASCRO. 1979; 13:147.

22. Vithanaarachchi SN, Nawarathna LS. Prevalence of anterior cross bite in preadolescent orthodontic patients attending an orthodontic clinic. Ceylon Med J. 2017; 62(3):189-92. [PMID: 29077365]

Received: 13.03.2018 • Accepted: 25.07.2018 


\title{
Učestalost malokluzija i stanje dentalnog zdravlja kod osmogodišnjaka na području opštine Foča
}

\author{
Marina Milinković1, Tanja Ivanović1, Predrag Nikolić2 , Ljiljana Stojanović², Željko Milosavljević , Jovana \\ Hrisa Samardžija', Aleksandra Šarac ${ }^{3}$ \\ 'Univerzitet u Istočnom Sarajevu, Medicinski fakultet, odsek Stomatologija, Foča, Bosna i Hercegovina; \\ ${ }^{2}$ Univerzitet u Beogradu, Stomatološki fakultet, Klinika za ortopediju vilica, Beograd, Srbija; \\ ${ }^{3}$ Dom zdravlja, Sokolac, Bosna i Hercegovina
}

\begin{abstract}
KRATAK SADRŽAJ
Uvod Karijes i ortodontske anomalije kod dece školskog uzrasta dovode do narušene estetike, poremećaja oralnih funkcija (žvakanje, gutanje i govor), povećane sklonosti nastanku trauma i nastanku parodontalnih bolesti.

Cilj ovog rada je bio da se provere dentalno zdravlje i učestalost ortodontskih anomalija kod dece uzrasta 8-9 godina na području opštine Foča.

Metode Istraživanje je sprovedeno u Osnovnoj školi „Sveti Sava“ u Foči, gde je pregledano ukupno 112 dece uzrasta 8-9 godina. Kod svakog učenika za koga je postojao informativni pristanak roditelja i direktora škole obavljen je stomatološki pregled standardnom stomatološkom metodom, ogledalom i sondom uz korišćenje veštačkog osvetljenja. Deca su dobila upute o pravilnoj ishrani, higijeni, zaštiti zuba i eliminaciji loših navika.

Rezultati Kod 112 pregledanih dečaka i devojčica odabranih uzrasta utvrđen je veoma visok karijes indeks osoba (Klo) - od 78,57\%. Ukupno je pronađeno 548 karijesom zahvaćenih mlečnih zuba (dečaci 331 (24,62\%); devojčice $217(16,14 \%)$ ( $p<0,05)$ ). Kod ukupno 59 ispitanika pronađen je karijes stalnih zuba (dečaci $39(2,9 \%)$; devojčice $20(1,5 \%)(p<0,05)$ ). Sagitalne nepravilnosti zagrižaja su bile zastupljene kod ukupno 39 (34,82\%) dece, dok se ukupno 38 (33,92\%) anomalija odnosilo na vertikalne nepravilnosti zagrižaja, pri čemu je $10(8,92 \%)$ ispitanika imalo otvoren zagrižaj, a 28 ispitanika (25\%) dubok zagrižaj ( $p>0,05)$.

Zaključak Kod osmogodišnjaka je pronađen veliki broj karijesom zahvaćenih mlečnih zuba (548) i velika zastupljenost ortodontskih anomalija, od kojih su najzastupljenije sagitalne nepravilnosti zagrižaja, koje su pronađene kod 39 ispitanika.

Ključne reči: karijes; malokluzije; zub
\end{abstract}

\section{UVOD}

Oralne bolesti i poremećaji oralnog zdravlja imaju važno mesto u humanoj patologiji i mogu negativno uticati na kvalitet života deteta [1]. Karijes i parodontopatija su najrasprostranjenije bolesti savremenog doba. Problem karijesa je u tome što najčešće oboljevaju deca i ujedno je jedno od najčešćih infektivnih multifaktorskih oboljenja detinjstva, koje utiče na estetske i funkcionalne karakteristike [2]. Veliki broj opštih i lokalnih, unutrašnjih i spoljašnjih faktora se dovodi u vezu sa nastankom karijesa. Opšti i lokalni faktori su: rasa, nasledni činioci, životno doba pojedinca, pol, funkcija endokrinih žlezda, ishrana, mikroorganizmi, pljuvačka, oblik i raspored zuba, jatrogeni faktori, loša oralna higijena i drugi [3]. Malokluzija predstavlja stanje poremećaja normalne okluzije (zagrižaja) kod pacijenta [4]. Obično imaj multifaktorsko poreklo (genetske i hereditarne komponente, nepravilna ishrana, karijes zuba, prekobrojni zubi i prerani gubitak mlečnih zuba) [5].

Ortodontske anomalije i zubni karijes su dva najrasprostranjenija stomatološka oboljenja dece, i činjenica da se nalaze u permanentnom porastu ukazuje na njihovu uzajamnu povezanost i uslovljenost [6]. Poznato je da karijes, a naročito onaj na aproksimalnim površinama mlečnih zuba, ima veliki uticaj na stvaranje ortodontskih anomalija. Isto tako, i svaka prerana ekstrakcija mlečnih molara uzrok je sekundarne teskobe [7]. S obzirom na to da je najidealnije vreme za početak ortodontske terapije predpubertetski uzrast, cilj našeg istraživanja je bio da se utvrde oralni status i zastupljenost malokluzija kod osmogodišnjaka na području opštine Foča, te dobijeni rezultati uporede s onima iz drugih delova $\mathrm{BiH}$, zemalja u regiji, odnosno nekih razvijenijih država u svetu.

\section{MATERIJAL I METODE}

Ova studija je urađena na području opštine Foča, gde je ukupno pregledano 112 dece uzrasta 8-9 godina (drugi i treći razred). Izabrano godište je relevantno zbog perioda mešovite denticije, smene zuba i predpubertetskog skoka rasta, kada terapija ortodontskim mobilnim aparatima pruža najbolje efekte. Studija je sprovedena u toku 2017. godine u Osnovnoj školi „Sveti Sava“ u Foči. Preglede su obavljali lekari sa katedre za dečiju i preventivnu stomatologiju sa ortodoncijom. Pre početka pregleda za svako dete je postojala pismena saglasnost za učešće u studiji od strane roditelja, direktora škole i Ministarstva prosvete i kulture Republike Srpske. Deca koja nisu imala pismenu saglasnost od strane roditelja isključena su iz studije. Studija je odobrena i od strane etičkog komiteta Medicinskog fakulteta u Foči. Osnovne aktivnosti u toku istraživanja bile su: zdravstveno prosvećivanje dece, pregled usta i zuba, evidencija u stomatološke kartone, grupni zdravstveni razgovor sa decom, individualni zdravstveni razgovor sa roditeljima i nastavnicima o načinu održavanja oralne higijene i savetovanje roditelja o pravilnom načinu ishrane.

Pre svakog pregleda deci su uz prisustvo nastavnog osoblja održana predavanja o važnosti zdravih zuba za opšte zdravlje, procesu nastanka karijesa, procesu nastanka plaka, dejstvu mikoroorganizama iz plaka na zube, važnosti pravilne ishrane za zdravlje zuba, načinu održavanja pravilne oralne higijene, povezanosti zdravlja zuba i higijene usne šupljine, važnosti i značaju fluor profilakse, značaju zalivanja fisura, vrsti pribora koji je neophodan za održavanje oralne higijene, kao i značaju kontrolnih pregleda za oralno zdravlje. Učenicima je i demonstrirano pravilno održavanje oralne higijene. Pregledi su obavljeni u učionicama škola, pri dnevnom 
osvetljenju uz korišćenje stomatološke sonde i ogledalca. Za procenu rasprostranjenosti karijesa korišćen je KlajnPalmerov sistem (KEP). Kod svakog deteta utvrđeno je prisustvo ili odsustvo ortodontskih anomalija. Na osnovu okluzalnog odnosa zuba gornje i donje vilice određivana je klasa po Angleu. Vertikalne nepravilnosti zagrižaja su merene pomoću ortodontskog milimetarskog linijara. Za statističku obradu podataka korišćen je neprametrijski test, Chi-square test, a od parametrijskih testova t-test nezavisnih uzorka, na nivou verovatnoće od $5 \%(\mathrm{p}<0,05)$.

\section{REZULTATI}

Kliničkim pregledom kod ispitanika dobijeni su podaci o stanju zdravlja zuba (statusu zuba), međusobnom odnosu zubnih nizova i prisustvu ortodontskih anomalija. Kod 112 pregledanih dečaka i devojčica odabranog uzrasta u ovoj studiji ukupno je pronađeno 40,77\% karijesom zahvaćenih mlečnih zuba (dečaci $(24,62 \%)$; devojčice $(16,14 \%))(\mathrm{p}<0,05)$ (Tabela 1). Kod ukupno $4,38 \%$ ispitanika pronađen je karijes stalnih zuba (dečaci $(2,9 \%)$; devojčice $(1,5 \%))(\mathrm{p}<0,05))$ (Tabela 2). Karijes indeks osoba (KIo) bio je veoma visok i iznosio je 78,57\% (dečaci $55,68 \%$; devojčice $34,82 \%(\mathrm{p}>0,05))$.

Analizom podataka u odnosu na ortodontske anomalije utvrđeno je da su odstupanja od normalnog zagrižaja bila zastupljena u visokom procentu. Sagitalne nepravilnosti zagrižaja utvrđene su kod ukupno 34,82\% ispitanika (18,2\% dečaci, $16,6 \%$ devojčice, ( $p>0,05)$. Najčešći odnos vilica po Angleovoj klasifikaciji kod dece u ovom uzrastu bila je I klasa, koja je registrovana kod ukupno 65,17\% ispitanika (Tabela 3), normalan odnos I klase je zabeležen kod ukupno 47,32\% ispitanika, dok se $17,85 \%$ odnosilo na iregularnosti I klase $(\mathrm{p}>0,05)$.

U odnosu na ovu klasifikaciju, najčešća nepravilnost zagrižaja je II klasa, koja je registrovana kod ukupno 26,78\% ispitanika. II/1 klasa, koja se karakteriše distalnim zagrižajem sa protruzijom zuba, bila je zastupljena kod ukupno 16,96\% dece, dok je II/2 klasa sa distalnim zagrižajem i retruzijom zuba registrovana kod 9,82 (Tabela 3). U odnosu na sigitalnu ravan najmanji broj nepravilnosti zagrižaja odnosio se na malokluziju III klase, koja je pronađena kod ukupno 8,03\% ispitanika ( $\mathrm{p}>$ 0,05 ) (Tabela 3). Jednostavan obrnut preklop sekutića (Slika 1) kao dentoalveolarni oblik treće klase je bio najizraženija nepravilnost i registrovan je kod ukupno 6,72\% dece.

$\mathrm{U}$ odnosu na vertikalnu ravan, nepravilnosti zagrižaja su utvrđene kod ukupno 33,92\% anomalija. Otvoren zagrižaj (Slika 2) bio je zastupljen kod ukupno 10 (8,92\%) ispitanika, dok je kod 28 (25\%) ispitanika registrovan neki od oblika dubokog preklopa sekutića $(\mathrm{p}>0,05)$ (Tabela 4$)$.

\section{DISKUSIJA}

U ovoj studiji uočena je visoka prevalenca karijesa kod školske dece na području opštine Foča. Na osnovu dosadašnjih studija i pregledane literature poznato je da sociodemografski faktori, informisanost roditelja i saradnja sa stomatološkom službom imaju uticaja na opšte zdravlje deteta. Kada se uzmu u obzir rezultati istraživanja iz ove studije, čini se da je područje opštine Foča po učestalosti pojave karijesa, prema dobijenim vrednosti- ma karijes indeks osoba (Kio), 78,57\%, među vodećim. Ovako visoke vrednosti karijes indeks osoba su u skladu sa rezultatima Davidovića i saradnika, koji su na području istočnog dela $\mathrm{BiH}$ pronašli ukupno 43,5\% dece sa karijesom [8]. Takođe, Kobašlija i saradnici su na području opštine Sarajevo (2000) našli visoke (89\%) vrednosti za (Kio) [9]. Navedeni rezultati su karakteristični za nerazvijene ili zemlje u razvoju, gde su ove vrednosti vrlo visoke (87-91\%) [10], dok su vrednosti Kio u razvijenim zemljama znatno niže $(28,8 \%)[11,12]$.

Ipak, rezultati koji se odnose na karijes u mešovitoj denticiji mogu da se uporede i sa nekim evropskim zemljama [13], gde su takođe pronađene veće $(44,6 \%)$ vrednosti karijesa mlečnih zuba kod školske dece. Ali u odnosu na našu studiju, evropske zemlje imaju znatno veću $(55,4 \%)$ zastupljenost dece sa svim zdravim zubima, što na našim područjima nije slučaj, a to pokazuje procenat od $21,4 \%$ dece sa svim zdravim zubima. Uzimajući u obzir da znatno veći broj osmogodišnjaka ima visoku učestalost karijesnih i ekstrahovanih mlečnih zuba u odnosu na plombirane, jasno govori o problemu dugoročnih preventivnih programa i sistematske stomatološke zaštite.

Dosadašnja istraživanja na području Bosne i Hercegovine i susednih zemalja [8/10] pokazuju visoku (45-88,35\%) prevalencu karijesa na stalnim zubima kod školske dece. Naša istraživanja pokazuju znatno manju $(4,1 \%)$ učestalost karijesa u ovom uzrastu u odnosu na dosadašnje studije, što se može objasniti činjenicom da je to period rane mešovite denticije i da se radi o tek nedavno izniklim stalnim zubima. Ali kada se pogleda distribucija KEP, zapažamo znatno više karijesnih zuba u odnosu na plombirane, naročito kod dečaka, što je jasan pokazatelj slabijih preventivno- profilaktičkih mera i saradnje sa stomatologom.

U odnosu na ortodontske nepravilnosti u toku ove studije pronađeno je ukupno 52,67\% ortodontskih anomalija, što odgovara najčešće dobijenim rezultatima u toku ranije sprovedenih istraživanja u domaćoj i stranoj literaturi, gde procenat ovih anomalija varira od 29,42 do $81 \%[8,14]$.

U ovoj studiji najzastupljeniji oblik malokluzija prema Angleovoj klasifikaciji bila je klasa I (65,17\%), što je u skladu sa rezultatima iz ranijih studija $(62,9 \%)[14,15,16]$. U odnosu na ovu klasu, 47,32\% ispitanika je imalo normalnu okluziju I klase, što je znatno više u odnosu na rezultate iz drugih studija (6,5-10\%), dok se na nepravilnost I klase sa teskobom u frontu odnosilo ukupno $17,85 \%$, što je niže u odnosu na svetsku populaciju [14].

Učestalost II klase (26,78\%) niža je u odnosu na rezultate drugih studija gde je procenat ovih anomalija znatno viši (58-65\%) [17, 18], što se može objasniti slabijom zastupljenošću loših navika i uspešnom primenom preventivnih mera i mera interceptivne ortodoncije u periodu mlečne denticije. U odnosu na ovu malokluziju dobijeni rezultati pokazuju da je zastupljenija II/1 u odnosu na II/2 klasu, što je u skladu sa ranije objavljenim istraživanjima u kojima je klasa II/1 (35\%) bila zastupljenija u odnosu na II/2 klasu (17\%) [8].

Malokluzije III klase su bile zastupljenje ( $8,03 \%)$, što je više u odnosu na istraživanja iz evropskih zemalja (2,5\%) [19]. S obzirom na činjenicu da se veći procenat $(6,72 \%)$ ove malokluzije odnosi na decu sa jednostavnim obrnutim preklopom sekutića, ovoliki procenat može da se objasni slabom primenom interceptivnih i preventivnih mera u prevenciji navedenih ne- 
pravilnosti koje u ranom uzrastu imaju veliki efekat u terapiji ortodontskih anomalija [20].

Vertikalne nepravilnosti zagrižaja u ovoj studiji su bile zastupljene kod ukupno 33,92\% ispitanika. U odnosu na svetsku populaciju, gde se smanjena dubina preklopa sekutića kreće oko 30-50\%, u ovoj studiji dubok zagrižaj je pronađen kod ukupno $25 \%$ ispitanika, što je manje u odnosu na druga istraživanja [20], ali se ujedno poklapa sa studijom koju su sproveli Jović i autori [21], koja pokazuje da se dubina preklopa menja u intervalima i da se u periodu od 7. do 10. godine povećava dubina preklopa. Ovi podaci se poklapaju i sa prevalencom II klase, koja je povezana sa dubokim preklopom sekutića i distalnim zagrižajem. Otvoren zagrižaj je registrovan kod ukupno 8,92\% dece, što je znatno manje u odnosu na istraživanja drugih autora gde je prevalenca ove anomalije znatno zastupljenija (26,7\%) [22]. Ovi rezultati se mogu objasniti manjom učestalošću loših navika kod osmogodišnjaka kao glavnog etiološkog faktora u nastanku otvorenog zagrižaja.

\section{ZAKLJUČAK}

Prevalenca ortodontskih anomalija u odabranom uzorku školske dece na području opštine Foča je bila visoka. Najčešće su registrovane II klasa, zatim dubok zagrižaj, teskoba u frontu, otvoren zagrižaj i obrnut preklop sekutića. Frekvenca karijesa u ukupnom uzorku (KIo) bila je veoma visoka i to češće kod dečaka u odnosu na devojčice. Radi očuvanja mlečnih zuba kao čuvara prostora i potporene zone potrebno je uvesti obavezno saniranje mlečnih zuba pre upisa u škole, kao i redovne preventivno- profilaktičke i interceptivne mere u cilju sprečavanja nastanka ozbiljnijih ortodontskih problema u kasnijem uzrastu. 